\title{
ПОРУШЕННЯ ВМІСТУ ВІДНОВЛЕНОГО ГЛУТАТІОНУ В ЛЕГЕНЯХ ЩУРІВ НА ТЛІ ГОСТРОЇ КРОВОВТРАТИ, УСКЛАДНЕНОЇ ІШЕМІЄЮ- РЕПЕРФУЗІЄЮ КІНЦІВКИ, ТА ЇХ КОРЕКЦІЯ КАРБАЦЕТАМОМ
}

Вступ. Легені належать до органів, які особливо чутливі до системних патогенних чинників, зумовлених гострою крововтратою та ішемічно-реперфузійним синдромом. В їх основі лежить активація процесів ліпопероксидації з виснаженням антиоксидантного захисту. Однак динаміку вмісту відновленого глутатіону (GSH) у легенях за умов гострої крововтрати, ішемії-реперфузії кінцівки та їх поєднання вивчено недостатньо, немає даних про коригувальний вплив карбацетаму.

Мета дослідження - 3'ясувати особливості порушень вмісту відновленого глутатіону в легенях щурів у динаміці гострої крововтрати, ускладненої ішемією-реперфузією кінцівки, та ефективність їх корекції карбацетамом.

Методи дослідження. Дослідження проведено на 216-ти білих нелінійних щурах-самцях масою 200-220 2. Усі експерименти виконано під тіопентал-натрієвим наркозом. У тварин моделювали ішемію-реперфузію кінцівки, гостру крововтрату і поєднували ці ушкодження. В окремій групі проводили корекцію виявлених порушень карбацетамом. Через 1 і 2 год, а також через 1, 7 та 14 діб у легенях піддослідних тварин визначали вміст GSH.

Результати й обговорення. За умов ішемії-реперфузії кінцівки вміст у легенях GSH через 1 год експерименту, порівняно з контролем, істотно зростав, що, очевидно, мало компенсаторний характер. У подальшому показник статистично вірогідно знижувався, проте до 14 год повторно підвищувався $i$ досягав рівня контролю. При гострій крововтраті вміст GSH у всі терміни спостереження, порівняно 3 контролем, суттєво знижувався і ставав меншим порівняно з групою, в якій моделювали лише ішемію-реперфузію кінцівки. Після ускладнення гострої крововтрати ішемією-реперфузією кінцівки глутатіонова антипероксидазна система порушувалась ще більше, особливо через 7 і 14 діб експерименту. Застосування карбацетаму за умов ішемії-реперфузії кінцівки, гострої крововтрати та їх поєднання супроводжувалося вираженим позитивним ефектом, який полягав у зменшенні затрат GSH у нейтралізації прооксидантних чинників і ендотоксинів у легенях.

Висновки. Моделювання гострої крововтрати та ї̈ ускладнення ішемією-реперфузією кінцівки, порівняно з контролем, супроводжується зменшенням вмісту в легенях GSH 31 год до 14 діб. Додаткова ішемія-реперфузія кінцівки через 7 і 14 діб призводить до статистично більшого зниження досліджуваного показника. Застосування за цих умов карбацетаму, порівняно з тваринами без корекції в легенях, через 7 і 14 діб супроводжується меншим виснаженням GSH.

КЛЮЧОВІ СЛОВА: гостра крововтрата; ішемія-реперфузія кінцівки; легені; відновлений глутатіон; карбацетам.

ВСТУП. Легені належать до органів, які особливо чутливі до системних патогенних чинників різної етіології з розвитком гострого ураження $[1,2]$. Одним 3 таких $€$ гостра крововтрата 3 кінцівок, яка на сьогодні займає ключове місце серед причин смерті поранених та постраждалих у локальних збройних конфрліктах і після терористичних атак [3]. У патогенезі гострої крововтрати основну роль відіграє гіпоперфузія 3 розвитком гіпоксії, що супроводжується актива(c) О. В. Стахів, А. А. Гудима, І. В. Корда, Ю. В. Угляр, 2020. цією процесів ліпідної пероксидації клітинних мембран, збільшенням їх проникності та розвитком синдрому ендогенної інтоксикації. Усі ці процеси $є$ пусковими чинниками системної реакції організму на запалення, що при неадекватному лікуванні може призвести до поліорганної диссрункції та недостатності $[4,5]$.

Більшість поранених і постраждалих з масивною крововтратою госпіталізують із накладеним кровоспинним джгутом, максимально безпечний термін застосування якого становить 
2 год. Однак, як показали дослідження окремих авторів, двогодинна ішемія кінцівки з наступною реперфузією істотно погіршує перебіг гострої крововтрати і супроводжується розвитком дисфрункції внутрішніх органів [6]. В основі патогенезу виявлених порушень, як відмічають автори, лежить нашарування патогенних механізмів гострої крововтрати й ішемічно-реперфузійного синдрому, що насамперед стосується значної активації процесів ліпопероксидації з виснаженням антиоксидантного захисту [7, 8].

Вагому роль в антиоксидантному захисті відіграє глутатіонова антипероксидазна система. Ключовим ії елементом $є$ відновлений глутатіон (GSH), який акцептує гідроксильні радикали, під впливом глутатіонпероксидази нейтралізується гідрогену пероксид. Крім цього, під впливом глутатіонтрансорерази бере активну участь у знешкодженні ксенобіотиків та ендогенних токсинів [9].

Однак динаміку вмісту GSH у легенях за умов гострої крововтрати, ішемії-реперфузії кінцівки та їх поєднання вивчено недостатньо, немає даних про вплив на глутатіонову антипероксидазну систему карбацетаму - препарату з вираженим позитивним впливом на ензимну ланку антиоксидантного захисту [6, 10].

Мета дослідження - 3'ясувати особливості порушень вмісту відновленого глутатіону в легенях щурів у динаміці гострої крововтрати, ускладненої ішемією-реперфузією кінцівки, та есрективність їх корекції карбацетамом.

МЕТОДИ ДОСЛІДЖЕННЯ. Дослідження проведено на 216-ти білих нелінійних щурах-самцях віком 6-8 місяців масою 200-220 г, яких утримували в одному приміщенні при постійній температурі $18-22{ }^{\circ} \mathrm{C}$ на стандартному режимі віварію. Усі експерименти виконано з дотриманням норм Європейської конвенції про захист хребетних тварин, що використовуються для дослідних та інших наукових цілей (Страсбург, 1986), ухвали Першого національного конгресу з біоетики (Київ, 2001) і наказу МОЗ України від 23.09.2009 р. № 690. Комісія з питань біоетики Тернопільського національного медичного університету імені І. Я. Горбачевського МОЗ України порушень морально-етичних норм при проведенні науково-дослідної роботи не виявила.

Усі експерименти виконано під тіопентал-натрієвим наркозом (40 мг/кг). Піддослідних тварин поділили на 5 груп: контрольну (6 щурів) і 4 дослідних. У 1-й дослідній групі (50 щурів) тваринам моделювали ішемію-реперфузію кінцівки шляхом накладання проксимально на ліву лапку смужки еластичного джгута "SWAT-T" (США) шириною 10 мм на 120 хв [10]. У 2-й дослідній групі (50 щурів) моделювали гостру крововтрату (20 \% від об'єму циркулюючої крові) шляхом пересікання стегнової вени. У 3-й дослідній групі (50 щурів) ці ушкодження поєднували. У 4-й дослідній групі тваринам 3 ішемією-реперфрузією кінцівки (20 щурів), гострою крововтратою (20 щурів) та їх поєднанням (20 щурів) внутрішньочеревно вводили карбацетам (Інститут фрізико-органічної хімії та вуглехімії НАН України, м. Донецьк) у дозі 5 мг на кілограм маси тварини [10]. Тварин контрольної групи тільки вводили в наркоз і брали для досліджень через 3 год.

Через 1 і 2 год, 1, 7 та 14 діб піддослідних тварин 1-3 груп, а через 7 і 14 діб - піддослідних тварин 4-ї групи виводили з експерименту методом тотального кровопускання із серця. Для досліджень брали легені, в яких визначали вміст відновленого глутатіону за рівнем утворення тіонітрофенільного аніона в результаті взаємодії SH-груп глутатіону 3 5,5-дитіобіс-2-нітробензойною кислотою [11].

Вірогідність відмінностей між дослідними групами оцінювали з використанням непараметричного критерію Манна - Уїтні.

РЕЗУЛЬТАТИЙ ОБГОВОРЕННЯ. РеЗУЛЬТаТИ досліджень показали (табл. 1), що у тварин, яким моделювали лише ішемію-реперфузію, концентрація GSH у легенях, порівняно з контролем, через 1 год експерименту статистично вірогідно зростала (в 1,5 раза, $p<0,05)$. Проте в наступні терміни рівень досліджуваного показника знижувався і ставав істотно меншим, ніж у контрольній групі: через 2 год - в 1,3 раза, через 1 добу в 2,0 рази, через 7 діб - у 2,1 раза $(p<0,05)$. Варто відзначити, що через 14 діб реперфузійного періоду концентрація GSH у легенях практично не відрізнялась від даних контрольної групи (p>0,05). У динаміці досліду вміст у легенях GSH досягав мінімальної величини через 1-7 діб експерименту і був статистично вірогідно меншим порівняно 31 та 2 год $(p<0,05)$. До 14-ї доби показник зростав і в цей термін ставав істотно більшим порівняно 31 i 2 год та 1-ю і 7-ю добами експерименту $(p<0,05)$.

Після моделювання гострої крововтрати вміст у легенях GSH уже з 1 год експерименту знижувався порівняно 3 контролем (на 20,9\%, p<0,05) і в усі наступні терміни досліду був статистично вірогідно меншим: через 2 год -у 2,1 раза, через 1 добу - в 5,5 раза, через 7 діб в 1,9 раза, через 14 діб - в 1,8 раза $(p<0,05)$. У динаміці показник досягав мінімальної величини через 1 добу та був істотно нижчим порівняно 3 попередніми термінами спостереження $(p<0,05)$. До 14-ї доби він зростав і ставав суттєво більшим порівняно 31 год та 1-ю добою експерименту 
$(p<0,05)$, проте залишався статистично вірогідно меншим, ніж через 1 год $(\mathrm{p}<0,05)$.

Після моделювання гострої крововтрати, ускладненої ішемією-реперфузією кінцівки, концентрація в легеня $\mathrm{GSH}$, порівняно з контролем, теж виявилася статистично вірогідно меншою: через 1 год - в 1,2 раза, через 2 год - у 2,3 раза, через 1 добу - в 6,6 раза, через 7 діб-у 3,6 раза, через 14 діб - у 2,6 раза $(p<0,05)$. У динаміці показник досягав мінімальної величини теж через 1 добу експерименту і був статистично вірогідно нижчим порівняно $з 1$ та 2 год $(p<0,05)$. До 14-ї доби він зростав, істотно перевищував 1 -шу добу експерименту $(p<0,05)$, проте не досягав рівня 1 год і залишався істотно меншим $(p<0,05)$.

Порівняння дослідних груп між собою дозволило встановити, що за умов гострої крововтрати та її ускладнення ішемією-реперфузією кінцівки вміст у легенях GSH у всі терміни експерименту був статистично вірогідно меншим порівняно з групою, в якій моделювали лише ішемію-реперфузію кінцівки $\left(\mathrm{p}_{1-2}<0,05, \mathrm{p}_{1-3}<0,05\right)$. При поєднанні гострої крововтрати з ішемією-реперфузією кінцівки, порівняно з групою, в якій моделювали тільки ішемію-реперфузію кінцівки, показник через 1 і 2 год та 1 добу експерименту істотно не відрізнявся $\left(\mathrm{p}_{2-3}>0,05\right)$. Проте через 7 і 14 діб у групі тварин 3 поєднаним ураженням він виявився статистично вірогідно нижчим (на 45,1 та 29,7 \% відповідно, $\left.\mathrm{p}_{2-3}<0,05\right)$.

Встановлено, що у тварин, яким моделювали ішемію-реперфузію кінцівки та проводили корекцію карбацетамом, рівень GSH у легенях через 7 діб був вірогідно вищим на 96,1 \% стосовно таких даних без корекції $(p<0,05)$. Варто відзначити, що через 14 діб реперфузійного періоду концентрація GSH практично не відрізнялася від показника контрольної групи і не залежала від коригувального чинника (табл. 2). У 2-й дослідній групі, в якій моделювали гостру крововтрату, вміст GSH у легенях за умов застосування карбацетаму через 7 діб істотно не відрізнявся порівняно з тваринами без корекції, проте через 14 діб статистично вірогідно зростав (на 29,7 \%, p<0,05). У 3-й дослідній групі, в якій моделювали гостру крововтрату й ішемію-реперфузію кінцівки, рівень GSH у легенях за умов корекції через 7 діб ставав статистично вірогідно більшим, порівняно з тваринами без корекції, у 2,4 раза (p<0,05), через 14 діб - на 91,9\%. Слід зауважити, що в усіх дослідних групах величина досліджуваного показника під впливом корекції карбацетамом не досягала рівня контрольної групи і залишалася статистично вірогідно меншою $(p<0,05)$.

Таким чином, за умов ішемії-реперфузії кінцівки вміст у легенях GSH через 1 год експерименту істотно зростав, що, очевидно, мало компенсаторний характер та описано в роботах інших авторів [9], які досліджували активність у легенях ензимної ланки антиоксидантного захисту: супероксиддисмутази і каталази. Якщо активність цих ензимів під впливом лише ішемії-реперфузії кінцівки в усі терміни була більшою, ніж у контрольній групі, то рівень у легенях GSH уже з 2 год експерименту знижувався. Отримані результати дозволяють припустити, що під впливом

Таблиця 1 - Динаміка вмісту відновленого глутатіону (нмоль/г тканини легень) у легенях щурів після гострої крововтрати, ускладненої ішемією-репердузією кінцівки $\left(\mathrm{Me}\left(\mathrm{Q}_{25} ; \mathrm{Q}_{75}\right)\right)$

\begin{tabular}{|c|c|c|c|c|c|}
\hline \multirow{2}{*}{ Дослідна група } & \multicolumn{5}{|c|}{ Термін реперфузійного періоду } \\
\hline & 1 год & 2 год & 1-ша доба & 7-ма доба & 14-та доба \\
\hline \multicolumn{6}{|c|}{ Контроль=32,1 $(30,1 ; 33,9)(n=6)$} \\
\hline $\begin{array}{l}\text { 1-ша (ішемія- } \\
\text { реперфузія) }\end{array}$ & $\begin{array}{c}49,0^{*} \\
(43,5 ; 52,5) \\
(n=10)\end{array}$ & $\begin{array}{c}24,4^{\star 1 \Gamma} \\
(22,9 ; 25,8) \\
(n=10)\end{array}$ & $\begin{array}{c}16,4^{\star 1,22} \\
(15,5 ; 17,5) \\
(n=10)\end{array}$ & $\begin{array}{c}15,5^{\star 1,2 г} \\
(14,2 ; 18,3) \\
(n=10)\end{array}$ & $\begin{array}{c}30,8^{1 г, 2 г, 7 д} \\
(22,2 ; 35,2) \\
(n=10)\end{array}$ \\
\hline$p_{1-2}$ & $<0,05$ & $<0,05$ & $<0,05$ & $<0,05$ & $<0,05$ \\
\hline $\begin{array}{l}\text { 2-га } \\
\text { (крововтрата) }\end{array}$ & $\begin{array}{c}25,4^{\star} \\
(20,8 ; 26,3) \\
(n=10)\end{array}$ & $\begin{array}{c}15,3^{\star 1 \Gamma} \\
(13,3 ; 15,7) \\
(n=10)\end{array}$ & $\begin{array}{c}5,8^{* 1 r, 2 r} \\
(4,9 ; 7,1) \\
(n=9)\end{array}$ & $\begin{array}{c}16,4^{\star 1 \Gamma, 1 A} \\
(15,3 ; 17,1) \\
(n=8)\end{array}$ & $\begin{array}{c}17,5^{\star 1 г, 1 д} \\
(14,5 ; 18,2) \\
(n=8)\end{array}$ \\
\hline$p_{2-3}$ & $>0,05$ & $>0,05$ & $>0,05$ & $<0,05$ & $<0,05$ \\
\hline $\begin{array}{l}\text { 3-тя (ішемія- } \\
\text { реперфрузія+ } \\
\text { крововтрата) }\end{array}$ & $\begin{array}{c}27,9^{*} \\
(25,1 ; 31,9) \\
(n=10)\end{array}$ & $\begin{array}{c}13,9 * 1 r \\
(12,1 ; 15,3) \\
(n=10)\end{array}$ & $\begin{array}{c}4,9 * 1 r, 2 \Gamma \\
(4,3 ; 5,9) \\
(n=8)\end{array}$ & $\begin{array}{c}9,0 * 1\ulcorner, 2 г, 1 д \\
(7,6 ; 9,7) \\
(n=8)\end{array}$ & $\begin{array}{c}12,3^{\star 1 г, 1 д, 7 д} \\
(11,7 ; 13,8) \\
(n=8)\end{array}$ \\
\hline$p_{1-3}$ & $<0,05$ & $<0,05$ & $<0,05$ & $>0,05$ & $<0,05$ \\
\hline
\end{tabular}

Примітки:

1. * - відмінності стосовно контрольної групи статистично вірогідні $(p<0,05)$.

2. $\mathrm{p}_{1-2}$ - вірогідність відмінностей між 1-ю і 2-ю дослідними групами.

3. $\mathrm{p}_{2-3}$ - вірогідність відмінностей між 2-ю і 3-ю дослідними групами.

4. $\mathrm{p}_{1-3}$ - вірогідність відмінностей між 1-ю і 3-ю дослідними групами.

5. 1г,2гі,7, - відмінності стосовно 1 і 2 год, а також 1-ї та 7-ї діб експерименту статистично вірогідні $(p<0,05)$. 
Таблиця 2 - Вплив карбацетаму на вміст відновленого глутатіону (нмоль/г тканини легень) у легенях щурів після гострої крововтрати, ускладненої ішемією-реперфузією кінцівки (Me (Q25; Q75))

\begin{tabular}{|c|c|c|c|c|}
\hline \multirow{3}{*}{ Дослідна група } & \multicolumn{4}{|c|}{ Термін реперфузійного періоду } \\
\hline & \multicolumn{2}{|c|}{ без корекції } & \multicolumn{2}{|c|}{ корекція карбацетамом } \\
\hline & 7-ма доба & 14-та доба & 7-ма доба & 14-та доба \\
\hline \multicolumn{5}{|c|}{ Контроль=32,1 $(30,1 ; 33,9)(n=6)$} \\
\hline $\begin{array}{l}\text { 1-ша (ішемія- } \\
\text { реперфузія) }\end{array}$ & $\begin{array}{c}15,5^{\star} \\
(14,2 ; 18,3) \\
(n=10)\end{array}$ & $\begin{array}{c}30,8 \\
(22,2 ; 35,2) \\
(n=10)\end{array}$ & $\begin{array}{c}30,4^{\#} \\
(28,6 ; 31,1) \\
(n=10)\end{array}$ & $\begin{array}{c}31,1 \\
(30,1 ; 33,3) \\
(n=10)\end{array}$ \\
\hline 2-га (крововтрата) & $\begin{array}{c}16,4^{*} \\
(15,3 ; 17,1) \\
(n=8)\end{array}$ & $\begin{array}{c}17,5^{\star} \\
(14,5 ; 18,2) \\
(n=8)\end{array}$ & $\begin{array}{c}13,8^{\star} \\
(13,5 ; 15,2) \\
(n=10)\end{array}$ & $\begin{array}{c}22,7^{\star \#} \\
(21,7 ; 24,2) \\
(n=10)\end{array}$ \\
\hline $\begin{array}{l}\text { 3-тя (ішемія- } \\
\text { реперфрузія+ } \\
\text { крововтрата) }\end{array}$ & $\begin{array}{c}9,0^{\star} \\
(7,6 ; 9,7) \\
(n=8)\end{array}$ & $\begin{array}{c}12,3^{\star} \\
(11,7 ; 13,8) \\
(n=8)\end{array}$ & $\begin{array}{c}22,4^{\star \#} \\
(21,6 ; 24,3) \\
(n=9)\end{array}$ & $\begin{array}{c}23,6^{\star \#} \\
(21,6 ; 25,2) \\
(n=9)\end{array}$ \\
\hline
\end{tabular}

Примітки:

1. * - відмінності стосовно контрольної групи статистично вірогідні $(p<0,05)$.

2. \# - відмінності, порівняно з тваринами без корекції, в межах однієї групи статистично вірогідні $(p<0,05)$.

токсинів, які надходять з ішемізованої кінцівки після її реперфузії, в легенях відбувається компенсаторне підвищення активності ензимів першої лінії, спрямованих на нейтралізацію активних фрорм кисню, проте відмічають значне виснаження глутатіонової антипероксидазної системи. Це, очевидно, пов'язано із ширшим спектром її антитоксичного впливу та виснаженням систем її відновлення.

Дане припущення було підтверджено на основі аналізу вмісту GSH після моделювання гострої крововтрати. За рахунок гіпоперфузії в організмі виснажується і ензимна ланка антиоксидантного захисту, що показано в роботах $[10,12]$, і неензимна, зокрема вміст GSH, який затрачається на процеси нейтралізації гідроксильних радикалів, гідрогену пероксиду та ендотоксинів. Проте після ускладнення гострої крововтрати ішемією-репердузією кінцівки глутатіонова антипероксидазна система ще більше порушувалась, особливо через 7 і 14 діб експерименту. Це вказує на ефект сумації обох патологічних впливів і підтверджує вагому роль цієї системи в гомеостатичному регулюванні про-та антиоксидантного балансу в легенях.

Застосування карбацетаму супроводжувалося вираженим позитивним ефектом, який полягав у зменшенні затрат GSH у нейтралізації прооксидантних чинників та ендотоксинів у легенях. Це призвело до істотного зростання його вмісту в легенях: за умов ішемії-реперфузії кінцівки - через 7 діб, гострої крововтрати - через 14 діб, їх поєднання - через 7 і 14 діб. Подібні результати отримали й інші автори при гострій крововтраті та ішемії-реперфузії кінцівки $[6,10]$. Можна припустити, що отриманий ефект карбацетаму зумовлений рядом фрармакофорних угруповань, які мають повну структурну схожість з відомими антиоксидантами, антигіпоксантами, актопротекторами. Таким чином, карбацетам $€$ перспективним засобом корекції порушень, спричинених гострою масивною крововтратою та ішемією-реперфузією кінцівки.

ВИСНОВКИ. 1. За умов моделювання ішемії-реперсузії кінцівки вміст у легенях GSH через 1 год експерименту істотно зростає, що має компенсаторний характер, проте вже з 2 год експерименту знижується, досягаючи мінімальної величини через 7 діб. До 14-ї доби показник нормалізується.

2. Моделювання гострої крововтрати та її ускладнення ішемією-реперорузією кінцівки супроводжується більшим зниженням вмісту в легенях GSH, який досягає мінімуму через 1 добу і до 14-ї доби залишається істотно меншим порівняно з контролем. Через 7 і 14 діб додаткова ішемія-реперсрузія кінцівки зумовлює статистично більше зниження досліджуваного показника.

3. Застосування карбацетаму за умов моделювання ішемії-реперфузії кінцівки, гострої крововтрати та їх поєднання супроводжується меншим виснаженням у легенях GSH, що, порівняно з тваринами без корекції, призводить до істотного зростання його вмісту в легенях: при ішемії-реперфузії кінцівки - через 7 діб, гострій крововтраті - через 14 діб, їх поєднанні - через 7 і 14 діб.

Перспективи подальших досліджень. У перспективі варто дослідити стан глутатіонової антипероксидазної системи інших внутрішніх органів за умов ішемії-реперфузії кінцівки, гострої крововтрати та їх поєднання, а також ефективність карбацетаму. 


\section{СПИСОК ЛІТЕРАТУРИ}

1. Особливості антиоксидантної системи захисту у динаміці розвитку гострого респіраторного дистрессиндрому та при різних методах корекції у щурів / М. І. Марущак, С. О. Савчук, У. П. Гевко, О. В. Олійник // Scientific Journal "ScienceRise: Medical Science". 2017. - № 6 (14). - C. 18-23.

2. Incidence and outcomes of acute lung injury / G. D. Rubenfeld, E. Caldwell, E. Peabody [et al.] // New Engl. J. Med. - 2005. - 353, No. 5. - P. 1685-1693.

3. Point of injury tourniquet application during Operation Protective Edge-What do we learn? / A. Shlaifer, A. Yitzhak, E. N. Baruch [et al.] // J. Trauma Acute Care Surg. - 2017. - 83, Issue 2. - P. 278-283.

4. Гудима А. А. Антиоксидантно-прооксидантний та цитокіновий баланс у пізній період комбінованої травми в експерименті / А. А. Гудима, Т. В. Кащак, К. В. Шепітько // Світ медицини та біології. - 2019. № 1 (67). - C. 42-47.

5. Шацький В. Вплив артеріального джгута і реперфузії кінцівки на динаміку активності супероксиддисмутази і каталази у нирці // XXII Міжнар. мед. конгр. студентів та молодих вчених, 23-25 квіт. 2018 р. Тернопіль : ТДМУ, 2018. - С. 277-278.

6. Peculiarities of impairments of absorptive-excretory and glycogen synthesis functions of the liver in the presence of acute blood loss complicated by limb ischemia-reperfusion and their correction by carbacetam / I. I. Horban, A. A. Hudyma, R. V. Maksymiv, N. A. Dzhavadova // Journal of Education, Health and Sport. 2020. - 10 (5). - P. 301-314.

\section{REFERENCES}

1. Marushchak, M.I., Savchuk, S.O., Hevko, U.P., \& Oliynyk, O.V. (2017). Osoblyvosti antoksydantnoi systemy zakhystu u dynamitsi rozvytku hostroho respiratornoho dystres-syndromu ta pry riznykh metodakh korektsii u shchuriv [Peculiarities of antioxidant protection system in the dynamics of acute respiratory distress syndrome development and at different methods of its correction in rats]. Scientific Journal "ScienceRise: Medical Science", 6 (14), 18-23 [in Ukrainian].

2. Rubenfeld, G.D., Caldwell, E., Peabody, E., Weaver, J., Martin, D.P., Neff, M., ..., \& Hudson, L.D. Incidence and outcomes of acute lung injury (2005). New Engl. J. Med., 353, 5, 1685-1693.

3. Shlaifer, A., Yitzhak, A., Baruch, E.N., Shina, A., Satanovsky, A., Shovali, A., ..., \& Glassberg, E. (2017). Point of injury tourniquet application during Operation Protective Edge-What do we learn? J. Trauma Acute Care Surg., 83, 2, 278-283.

4. Hudyma, A.A., Kashchak, T.V., \& Shepitko, K.V. (2019). Antyoksydantno-prooksydantnyi ta tsytokinovyi balans u piznii period kombinovanoi travmy $v$ eksperymenti [Antioxidant-prooxidant and cytokine balance in the late period of combined trauma in the experiment]. Svit medytsyny ta biolohii - World of Medicine and Biology, 1 (67), 42-47 [in Ukrainian].

5. Shatskyy, V. (2018). Vplyv arterialnoho dzhhuta i reperfuzii kintsivky na dynamiku aktyvnosti superoksyddysmutazy i katalazy u nyrtsi [Influence of arterial tourniquet and limb reperfusion on the dynamics of superoxi-
7. Максимів Р. В. Динаміка балансу антиоксидантно-прооксидантних механізмів у внутрішніх органах під впливом артеріального джгута і реперсузії кінцівки / Р. В. Максимів, А. А. Гудима, В. М. Сидоренко // Шпитальна хірургія. Журн. імені Л. Я. Ковальчука. 2017. - № 1. - C. 37-44.

8. Volotovska N. V. Changes in the glutathione system's activity of internal organs in the first hours of experimental limb ischemia-reperfusion syndrome, combined with blood loss and mechanical injury / N. V. Volotovska, T. C. Nhokwara, I. V. Zhulkevych // Здобутки клініч. і експерим. медицини. - 2019. - № 1. - С. 23-27.

9. Свободнорадикальные процессы в биосистемах / [Т. Н. Попова, А. Н. Пашков, А. В. Семенихина и др.]. - Воронеж, 2008. - 192 с.

10. Shatskyi V. V. Significance of lipid peroxidation processes in renal excretory dysfunction in cases of acute blood loss complicated by limb ischemia-reperfusion and its correction / V. V. Shatskyi, A. A. Hudyma // Journal of Education, Health and Sport. - 2019. - 9, No. 11. P. 293-306.

11. Ellman G. L. Tissue sulfhydryl groups / G. L. Ellman // Arch. Biochem. Biophys. - 1959. - 82, No. 1. P. 70-77.

12. Зыблев С. Л. Состояние метаболизма при экспериментальной острой массивной кровопотере в зависимости от проводимой терапии / С. Л. Зыблев, 3. А. Дундаров // Новости хирургии. - 2013. - 21, № 5. - С. 3-10.

de dismutase and catalase activity in the kidney]. Proceedings of the Congress "XKHII Mizhnar. med. konhr. studentiv i molodykh vchenykh - XXII International Med. Congr. of Students and Young Scientists. (pp. 277-278). Ternopil: Ukrmedknyha [in Ukrainian].

6. Horban, I.I., Hudyma, A.A., Maksymiv, R.V., \& Dzhavadova, N.A. (2020). Peculiarities of impairments of absorptive-excretory and glycogen synthesis functions of the liver in the presence of acute blood loss complicated by limb ischemia-reperfusion and their correction by carbacetam. Journal of Education, Health and Sport, 10 (5), 301-314.

7. Maksymiv, R.V., Hudyma, A.A., \& Sydorenko, V.M. (2017). Dynamika balansu antyoksydantno-prooksydantnykh mekhanizmiv u vnutrishnikh orhanakh pid vplyvom arterialnoho dzhhuta i reperfuzii kintsivky [Dynamic of balance of antioxidant-prooxidant mechanism in internal organs Under the influence of blood harnesses and limb reperfusion]. Shpytalna khirurhiia. Zhurnal imeni L.Ya. Kovalchuka - Hospital Surgery. Journal named by L.Ya. Kovalchuk, 1, 37-44 [in Ukrainian].

8. Volotovska, N.V., Nhokwara, T.C., \& Zhulkevych, I.V. (2019). Changes in the glutathione systems activity of internal organs in the first hours of experimental limb ischemia-reperfusion syndrome, combined with blood loss and mechanical injury. Zdobutky klinich. i eksperym. medytsyny - Achievements of Clinical and Experiment. Medicine, 1, 23-27. 
9. Popova, T.N., Pashkov, A.N., \& Semenikhina, A.V. (2008). Svobodnoradikalnyye protsessy $v$ biosistemakh [Free radical processes in biosystems]. Voronezh [in Russian].

10. Shatskyi, V.V., \& Hudyma, A.A. (2019). Significance of lipid peroxidation processes in renal excretory dysfunction in cases of acute blood loss complicated by limb ischemia-reperfusion and its correction. Journal of Education, Health and Sport, 9, 11, 293-306.
11. Ellman, G.L. (1959). Tissue sulfhydryl groups. Arch. Biochem. Biophys, 82, 1, 70-77.

12. Zyblev, S.L., \& Dundarov, Z.A. (2013). Sostoyaniye metabolizma pri eksperimentalnoy ostroy massivnoy krovopotere $v$ zavisimosti ot provodimoy terapii [The state of metabolism in experimental acute massive blood loss, depending on the conducted therapy]. Novosti khirurgii Surgery News, 21, 5, 3-10 [in Russian].

\section{НАРУШЕНИЯ СОДЕРЖАНИЯ ВОССТАНОВЛЕННОГО ГЛУТАТИОНА В ЛЕГКИХ КРЫС НА ФОНЕ ОСТРОЙ КРОВОПОТЕРИ, ОСЛОЖНЕННОЙ ИШЕМИЕЙ- РЕПЕРФУЗИЕЙ КОНЕЧНОСТИ, И ИХ КОРРЕКЦИЯ КАРБАЦЕТАМОМ}

\section{Резюме}

Вступление. Легкие относятся к органам, которые особо чувствительны к системным патогенным фракторам, обусловленным острой кровопотерей и ишемическо-реперфузионным синдромом. В их основе лежит активация процессов липопероксидации с истощением антиоксидантной защиты. Однако динамика содержания восстановленного глутатиона (GSH) в легких в условиях острой кровопотери, ишемии-реперфузии конечности и их сочетания изучена недостаточно, нет данных о корректирующем влиянии карбацетама.

Цель исследования - выяснить особенности нарушений содержания восстановленного глутатиона в легких крыс в динамике острой кровопотери, осложненной ишемией-реперфузией конечности, и эфрфективность их коррекции карбацетамом.

Методы исследования. Исследование проведено на 216-ти белых нелинейных крысах-самцах массой 200-220 2. Все эксперименты выполнены под тиопентал-натриевым наркозом. У животных моделировали ишемию-реперфуузию конечности, острую кровопотерю и сочетали эти повреждения. В отдельной группе проводили коррекцию выявленных нарушений карбацетамом. Через 1 и 2 ч, а также через 1, 7 и 14 суток в легких экспериментальных животных определяли содержание GSH.

Результаты и обсуждение. В условиях ишемии-реперфузии конечности содержание в легких GSH через 1 ч эксперимента, по сравнению с контролем, существенно возрастало, что, очевидно, носило компенсаторный характер. В дальнейшем показатель статистически достоверно снижался, однако к 14 ч повторно повышался и достигал уровня контроля. При острой кровопотери содержание GSH во все сроки наблюдения, по сравнению с контролем, существенно снижалось и становилось меньше по сравнению с группой, в которой моделировали только ишемию-реперфузию конечности. После осложнения острой кровопотери ишемией-реперфузией конечности глутатионовая антипероксидазная система нарушалась еще больще, особенно через 7 и 14 суток эксперимента. Применение карбацетама в условиях ишемии-реперфузии конечности, острой кровопотери и их сочетания сопровождалось выраженным положительным эфроректом, который заключался в уменьшении затрат GSH в нейтрализации прооксидантных фракторов и эндотоксинов в легких.

Выводы. Моделирование острой кровопотери и ее осложнения ишемией-реперфузией конечности, по сравнению с контролем, сопровождается уменьшением содержания в легких GSH с 1 ч до 14 суток. Дополнительная ишемия-реперфузия конечности через 7 и 14 суток приводит к статистически большему снижению исследуемого показателя. Применение в этих условиях карбацетама, по сравнению с животными без коррекции в легких, через 7 и 14 суток сопровождается меньшим истощением GSH.

КЛЮЧЕВЫЕ СЛОВА: острая кровопотеря; ишемия-реперфузия конечности; легкие; восстановленный глутатион; карбацетам. 


\section{DISTURBANCE OF THE CONTENT OF RESTORATED GLUTATION IN THE LUNGS OF RATS ON THE BACKGROUND OF ACUTE BLOOD LOSS COMPLICATED BY ISCHEMIA-REPERFUSION OF THE LIMBS AND THEIR CORRECTION WITH CARBACETAM}

\section{Summary}

Introduction. The lungs are organs that are particularly sensitive to systemic pathogens caused by acute blood loss and ischemic-reperfusion syndrome. They are based on the activation of lipoperoxidation processes with depletion of antioxidant protection. However, the dynamics of the content of reduced glutathione in the lungs under conditions of acute blood loss, ischemia-reperfusion of the limb and their combination is insufficiently studied, there is no data on the corrective effect of carbacetam.

The aim of the study - to determine the features of disorders of the content of reduced glutathione in the lungs of rats in the dynamics of acute blood loss complicated by ischemia-reperfusion of the limb, and the effectiveness of their correction with carbacetam.

Research Methods. The study was performed on 216 white nonlinear male rats weighing 200-220 g. All experiments were performed under thiopental-sodium anesthesia. In animals, limb ischemia-reperfusion and acute blood loss were simulated and these lesions were combined. In a separate group, the detected disorders were corrected with carbacetam. After 1 and 2 hours, as well as after 1, 7 and 14 days in the lungs of experimental animals was determined the content of reduced glutathione.

Results and Discussion. Under conditions of ischemia-reperfusion of the limb, the content of reduced glutathione in the lungs after $1 \mathrm{~h}$ of the experiment compared with the control increases significantly, which is obviously compensatory. In the future, the rate is statistically likely to decrease, but up to 14 hours again increases and reaches the level of control. In the conditions of acute blood loss, the content of reduced glutathione in all terms of observation in comparison with the control is significantly reduced and becomes smaller in comparison with the group in which only ischemia-reperfusion of the limb was modeled. After the complication of acute blood loss by ischemia-reperfusion of the limb, the disorders of the glutathione antiperoxidase system became even greater, especially after 7 and 14 days of the experiment. The use of carbacetam in conditions of ischemia-reperfusion of the limb, acute blood loss and their combination is accompanied by a pronounced positive effect, which was to reduce the cost of reduced glutathione in the neutralization of prooxidants and endotoxins in the lungs.

Conclusions. Simulation of acute blood loss and its complication by limb ischemia-reperfusion compared with control is accompanied by a decrease in the content of reduced glutathione in the lungs from $1 \mathrm{~h}$ to 14 days. Additional ischemia-reperfusion of the limb after 7 and 14 days causes a statistically greater decrease in the studied indicator. The use of carabcetam in these conditions compared with animals without correction in the lungs after 7 and 14 days is accompanied by less depletion of reduced glutathione.

KEY WORDS: acute blood loss; ischemia-reperfusion of the limb; lungs; reduced glutathione; carbacetam.

Адреса для листування: А. А. Гудима, Тернопільський національний медичний університет імені І. Я. Горбачевського мОЗ України, майдан Волі, 1, Тернопіль, 46001, Україна, e-mail: arsgudyma@gmail.com. 